\title{
TELAAH PARADIGMA KEILMUAN: Kajian Pandangan Tokoh Tentang Paradigma Keilmuan
}

\author{
Oleh: \\ Nurul Milla \& Hariyanto \\ IAIN Jember \& IAI Ibrahimy Situbondo \\ nurulmillah92@gmail.com \& chori_p3m@yahoo.com
}

\begin{abstract}
Abstrack.
Paradigm is a fundamental image of a subject matter from a standpoint of science. Paradigm provides a groove about something that should be studied, what questions that should be presented and what rules that should be followed in that answer of argumentation. Therefore, the paradigm is like a frame that used by peoples to observe the world with their insight (world-view). This study only limited the discussion in the scientific paradigm in the perspectives of Descartes, Camto, Bacon, John Stuart Mill.
\end{abstract}

Key words: Scientific Paradigm, Descartes, Camto, Bacon, John Stuart Mill

\section{A. Pendahuluan}

Paradigma ilmu memiliki peranan penting dalam proses keilmuan, Paradigma ilmu berfungsi memberikan kerangka, mengarahkan, bahkan menguji konsistensi dari proses keilmuan. Tidak hanya itu, paradigma ilmu juga berfungsi sebagai lensa para ilmuan dan dapat mengamati memahami masalah-masalah ilmiah dalam bidang masing-masing dan jawaban-jawaban ilmiah terhadap masalah-masalah tersebut. Oleh karena itu, paradigma merupakan aspek yang begitu penting "urgent" dalam proses keilmuan dan dijadikan sebagai seperangkat kepercayaan atau keyakinan dasar yang menentukan seseorang dalam bertindak pada kehidupan sehari-hari atau dengan ibarat lain paradigma merupakan sebuah jendela tempat orang mengamati dunia luar dan tempat orang bertolak menjelajahi dunia dengan wawasannya dan sebagai kumpulan tata nilai sebagai pola pikir seseorang sebagai titik tolak pandangannya sehingga dapat membentuk citra subjektif seseorang mengenai realita dan akhirnya akan menentukan bagaimana seseorang menanggapi realita itu sebagaimana para filosof terdahulu yang mempunyai pendapat berbeda dalam meyakini sebuah penemuannya. 


\section{B. Pembahasan}

\section{Rene Descartes dan Paradigma Keilmuannya}

Rene descartes lahir di la haye, prancis, 31 maret 1596 dan meninggal distockholm ,swedia,11 february 1650 . descartes biasa dikenal sebagai cartesius . ia adalah seorang filsuf dan matematikawan prancis. Karyanya yang terpenting ialah discourse de la methode (1637) dan meditationes de prima philosophia (1641) ${ }^{1}$.

Rene descartes adalah putra keempat joachim descartes,seorang anggota perlemen propinsi renatus diprancis.kakeknya,piere descartes adalah seorang dokter,neneknya juga berlatar belakang kedokteran, decartes kecil yang mendapat nama baptis rene,tumbuh sebagai anak yang menampakkan bakatnya dalam bidang filsafat,sehingga ayahnya pun memanggilnya dengan julukan si filsuf keci².

Rene descartes termasuk tokoh filsafat abad modern, bahkan dialah pendiri dan pelopor utamanya. Ada perbedaan penting antara filsafat abad pertengahan dengan abad modern.perbedaan tersebut bukanlah dengan abad modern. Perbedaan tersebut bukanlah dilihat dari segi dikotomi mundur dan maju seperti halnya pada dunia ilmu pengetahuan.perbedaan keduanya lebih sering dilihat dari sudut ciri khasnya masingmasing.filsafat abad pertengahan bercirikan sinkretasi antara akal dan wahyu, anatara rasio dan agama, dengan kecenderungan untuk mencari pembenaran-pembenaran terhadap wahyu atau eksistensi tuhan melalui argumen-argumen filosofis. ingat, credo ut intelligam yang diintrodusir oleh anselem dkk. Perhatian filsafat selalu dicurahkan pada hal-hal yang bersifat konkret, seperti alam semesta, manusia hidup bermasyarakat dan sejarah. dengan kata lain segala segi dari kenyataan yang nampak dijadikan sasaran penyelidikan. ${ }^{3}$

Tokoh rasionalisme ini beranggapan bahwa dasar semua pengetahuan ada dalam pikiran. dalam buku Discourse de la methode ia menegaskan perlunya metode yang jitu sebagai dasar kokoh bagi semua pengetahuan, yaitu dengan menyangsikan segalanya, secara metodis. Kalau suatu kebenaran tahan terhadap ujian kesangsian yang radikal ini, maka kebenaran itu $100 \%$ pasti da menjadi landasan bagi seluruh

1. Robert c. Solomon dan Kathleen m. Higgins, A Short History Of Philosophy (New York: Oxford University, 1996)

2 Norman Kempt Smith, New Studies In The Philosophy Of Descartes(New York: Russek Inc,1996), hlm. 3. 12.

${ }^{3}$ Harun Hadiwijono, Sari Filsafat Baru (Yogyakarta: Yayasan Kanisius, 1980), hlm.

$100 \mid$ JURNAL LISAN AL-HAL 
pengetahuan. Namun dalam kesangsian metodis ini ternyata ada satu hal yang tidak dapat diragukan, yaitu "saya ragu-ragu". Ini bukan khayalan, tetapi kenyataan bahwa "aku ragu-ragu". Jika aku menyangsikan sesuatu, aku menyadari bahwa aku menyangsikan adanya, dengan lain kata, kesangsian itu langsung menyatakan adanya aku. itulah "cogito ergo sum", aku berfikir =menyadari maka aku ada. Itulah kebenaran yang tidak dapat disangkal lagi. Mengapa kebenaran itu pasti? Sebab, aku mengerti itu dengan " jelas dan terpilah-pilih " . "clearly and distinctly","clara et distincta". Artinya yang jelas dan terpilah-pilah itulah yang harus diterima sebagai benar. Dan itu menjadi norma descartes dalam menentukan kebenaran.

Descartes menerima 3 realitas atau substansi bawaan yang sudah ada sejak kita lahir, yaitu; Pertama, Realitas pikiran (res cogitan), Kedua, Realitas perluasan (res extensa,"extension") atau materi, Ketiga, Tuhan sebagai wujud yang seluruhnya sempurn, penyebab sempurna dari kedua realitas itu.

Pikiran sesungguhnya adalah kesadaran, tidak mengambil ruang dan tak dapat dibagi-bagi menjadi bagian yang lebih kecil. Materi adalah keluasan mengambil tempat dan dapat dibagi-bagi, dan tak memiliki kesadaran. Kedua substansi berasal dari tuhan, sebab hanya tuhan sajalah yang ada tanpa tergantung pada apapun descartes adalah seorang dualis, yang menerapkan pembagian tegas antara realitas pikiran dan realitas yang meluas manusia memiliki keduanya sedangkan binatang hanya memiliki realitas keluasan: manusia memiliki badan sebagaimana binatang dan memiliki pemikiran sebagaimana malaikat. Binatang adalah mesin otomat, bekerja mekanistik, sedang manusia adalah mesin otomat yang sempurna karena dari pikirannya ia memiliki kecerdasan. ${ }^{4}$

Dalam karyanya yang termasyhur, discourse on method, diajukan enam bagian penting berikut:

a. Menjelaskan masalah ilmu-ilmu yang diawali dengan menyebutkan akal sehat (common sense) yang pada umumnya dimiliki semua orang.menurut descartes akal sehat ada yang kurang, ada pula yang lebih banyak memilikinya, namun yang terpenting adalah penerapannya dalam aktifitas ilmiah. Metode yang ia coba temukan merupakan upaya untuk mengarahkan nalarnya sendiri secara optimal.descartes menandaskan bahwa pengetahuan budaya itu tetap kabur, pengetahuan bahasa memang berguna, puisi itu memang indah

4 Ali Maksum, Pengantar Filsafat Dari Masa Klasik Hingga Postmodernisme (Yogyakarta: Ar-Ruzz Media, 2011), hlm. 127. 
tapi memerlukan bakat.ia lebih tertarik pada bidang matematika yang dianggap belum dimanfaatkan secara optimal kemungkinannya yang cemerlang.filsafat bagi descartes rancu dengan gagasan yang acap kali saling bertentangan, oleh karena itu perlu dibenahi.

b. Menjelaskan kaidah-kaidah pokok tentang metode yang akan dipergunakan dalam aktifitas ilmiah. Bagi descartes, sesuatu yang dikerjakan oleh satu orang lebih sempurna daripada yang dikerjakan oleh sekelompok orang secara patungan.

c. Menyebutkan beberapa kaidah moral yang menjadi landasan bagai penerapan metode sebagai berikut: pertama, Mematuhi undangundang dan adat istiadat negeri, sambil berpegang pada agama yang diajarkan sejak masa kanak-kanak. Kedua, Bertindak tegas dan mantap, baik pada pendapat yang paling meyakinkan maupun yang paling meragukan. Ketiga, Berusaha lebih mengubah diri sendiri dari pada merombak tatanan dunia.

d. Menegaskan perihal dualisme dalam diri manusia yang terdiri atas dua substansi, yaitu res cogitans (jiwa bernalar) dan res extence (jasmani yang meluas). Tubuh (res extensa) diibaratkan dengan mesin, yang tentunya karena ciptaan tuhan maka tertata lebih baik. Ketergantungan antara dua kodrati ialah bahwa jiwa bernalar dan kodrat jasmani, jiwa secara kodrati tidak mungkin mati bersama dengan tubuh. Jiwa manusia itu abadi.

e. Dua jenis pengetahuan, yaitu pengetahuan spekulatif dan pengetahuan praktis. Pengetahuan praktis terkait dengan objek-objek konkret seperti api, air. Udara, planet, dan lain-lain sedang pengetahuan spekulatif menyangkut hal-hal yang bersifat filosofis. Berkat kedua pengetahuan inilah manusia menjadi penguasa alam.

Langkah-langkah yang dikemukakan descartes tersebut menggambarkan suatu sikap-metodis dalam upaya memperoleh kebenaran yang pasti. Karena itulah metode fisafat descartes sering juga disebut dengan metode skeptis, artinya meragukan segala sesuatu sebelum ditemukan kebenaran yang pasti. ${ }^{5}$

Discourse de la methode yang berarti urain tentang metode yang isinya melukiskan perkembangan intelektualnya.didalam karyanya inilah ia menyatakan ketidakpuasan atas filsafat dan ilmu pengetahuan yang menjadi bahan penyeledikannya. Dalam bidang ilmiah tidak ada sesuatu pun yang dianggap pasti; semuanya dapat dipersoalkan dan pada

5 Maksum, Pengantar Filsafat,.... hlm. 129.

$102 \mid$ JURNAL LISAN AL-HAL 
kenyataannya memang dipersoalkan juga. Satu-satunya kekecualiannya adalah ilmu pasti.demikian menurut descarets. ${ }^{6}$

Agar filsafat dan ilmu pengetahuan dapat diperbaharui,maka memerlukan metode yang baik begitulah pendapat descartes.hal ini mengingat bahwa terjadinya kesimpangsiuran dan ketidakpastian dalam pemikiran-pemikiran filsafat disebabkan oleh karena tidak adanya suatu metode yang mapan, sebagai pangkal tolak yang sama bagi berdirinya suatu filsafat yang kokoh dan pasti. Ia sendiri berfikir sudah mendapatkan metode yang dicarinya itu, yaitu dengan menyangsikan segala-galanya atau keragu-raguan.ia bermaksud bahwa kesangsian atau keragu-raguan ini harus meliputi seluruh pengetahuan yang yang ia miliki.

Lebih jelas uraian descartes tentang bagaimana memperoleh hasil yang shahih (adequate) dari metode yang hendak dicanangkannya dapat dijumpai dalam bagian kedua dari karyanya Anaximenes Discourse On Methode yang menjelaskan perlunya memperhatikan hal-hal berikut ini.

a. Tidak menerima sesuatu pun sebagai kebenaran, kecuali bila melihat hal itu sungguh-sungguh jelas dan tegas (clearly and distinctly), sehingga tidak ada suatu keraguan apa pun yang mampu merobohkannya.

b. Pecahkanlah setiap kesulitan, masalah atau sebanyak mungkin bagian, sehingga tidak ada suatu keraguan apapun yang mampu merobohkannya.

c. Bimbinglah pikiran dengan teratur, dengan memulai dari hal yang sederhana dan mudah diketahui, kemudian secara bertahap sampai pada yang paling sulit dan kompleks.

d. Dalam proses pencarian dan pemeriksaan hal-hal sulit, selamnya harus dibuat perhitungan-perhitungan yang sempurna serta pertimbangan-pertimbangan yang sempurna serta pertimbangan yang menyeluruh, sehingga kita menjdi yakin bahwa tidak ada satupun yang mengabaikan atau ketinggalan dalam penjelajahan itu. ${ }^{7}$

\section{Fransis Bacon dan Paradigma Keilmuannya}

Fransis bacon, lahir di london, inggris dan belajar di cambridge. Francis Bacon adalah seorang filosof inggris yang terkenal sebagai pelopor empirisme inggris, namun bukan berarti ia ateis. Ia berpendapat bahwa filsafat harus dipisahkan dari teologi, bukan dicampur sebagaimana

${ }^{6}$ Juhaya S. Praja,Aliran-Aliran Filsafat Dan Etika (Bandung: Kencana, 2003), hlm. 94.

${ }^{7}$ Praja, aliran-aliran filsafat dan etika, hlm. 97.

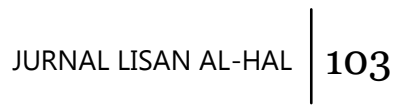


skolatisme. Urusan teologi hanya bisa diketahui oleh wahyu. Sedangkan filsafat hanya pada akal semata, karena itulah dia termasuk pendukung doktrin "kebenaran ganda" yakni akal dan wahyu, sedangkan agama yang dianut bacon adalah ortodoks.

Bacon lahir pada tanggal 22 januari 1561 di yourk house,london. Ayahnya adalah pejabat tinggi kerajaan inggris. Pada usia 12 tahun, bacon telah belajar ditrinity college, Cambridge University. Setalah usai pendidikan di Cambridge, ia diangkat sebagai staf kedutaan inggris diprancis. Pada usia yang cukup muda 23 tahun ia telah diangkat menjadi anggota parlemen. Pada tahun 1618, james I mengangkatnya menjadi lord chancellor dan kemudian menjadi Viscount St. Albans. Setelah lima tahun dari jabatannya (1626), dia meninggal karena kedinginan ketikan melakukan eksperimen pendinginan dengan cara membungkus seekor ayam dengan salju. ${ }^{8}$

Karya tulis bacon yang terkenal adalah the advancement of learning, New Atlantis, dan Novunm Organum. secara umum pandangan bacon bisa dikatakan praktis,konkret dan utilitaris. Bagi bacon untuk mengenal sifat-sifat segala sesuatu perlu penelitian yang empiris. Pengalamanlah yang menjadi dasar pengetahuan. Apa yang diungkapkan plato menjadi semboyan bacon, pengetahuan adalah kekuasaan (konwledge is power). Menguasai kekuatan-kekuatan dengan penemuan dan ciptaan ilmiah.

Dalam buku novun organum, bacon menyempurnakan metode ilmiah induksi menurutnya, logika silogisme tradisional tidak sanggup lagi menghasilkan penemuan empiris, ia hanya dapat membantu mewujudkan konsekwensi deduktif dari apa yang sebenarnya telah diketahui, agar penngetahuan terus berkembang dan memunculkan teori-teori hukum baru, maka metode deduktif harus ditinggalkan dan diganti dengan induktif modern.Bacon memang bukan penemu murni metode induksi tradisionalis dengan eksperimentasi yang sistematis, observasi yang ekstensif demi mendapatkan kebenaran ilmiah yang konkret, praktis, mensistematisasi prosedur ilmiah secara logis dan bermanfaat bagi manusia.

Bacon mempunyai jasa besar yang telah meletakkan rumusan sistematika ilmu, dikarenakan menurutnya, ada keterkaitan antara "potensi" manusia dengan objek-objek penyelidikan. Manusia yang memiliki" jiwa" berkemampuan (daya) triganda,yaitu: ingatan, khayalan,

8 Junjun S. Suriasumantri, Filsafat Ilmu Sebuah Pengantar Populer, (Jakarta: Pustaka Sinar Harapan), hlm. 324.

104 JURNAL LISAN AL-HAL 
dan akal. Ketiganya merupakan dasar pengetahuan.khusus untuk kemampuan daya akal terbagi menjadi tiga cabang pertama ilmu tentang ketuhanan. Kedua: ilmu tentang kemanusiaan, ketiga:ilmu tentang alam. Cabang ilmu tentang alam ia bedakan menjadi ilmu teoritis dan terapan bidang teoritis sendiri meliputi fisika dan metafisika, sedangkan bidang ilmu terapan meliputi mekanika dan magika. ${ }^{9}$

Menurut bacon, tujuan ilmu adalah penguasaan manusia terhadap alam, ilmu harus mempunyai kegunaan praktis dan menambah superioritas manusia terhadap alam semesta. Semboyan bacon yang terkenal adalah knowledge is power. Dengan ilmu manusia akan dapat menundukkan alam. Ilmu-ilmu yang ada sekarang ini, menurut bacon, tidak berguna untuk menyuburkan penemuan-penemuan, dan logika kita sekarang tidak berguna untuk mencapai tujuan membangun ilmu. Dalam bukunya Novun organum, ada doktrin negatif dan doktrin positif. Doktrin negatif dijelaskan oleh bacon dengan istilah jenis-jenis "idols", yang telah mendominasi dan menjerumuskan pikiran manusia, yang menghambat penguasaan ilmu pengetahuan yang sebenarnya antara lain

a. pertama, idol of the tribe, yaitu kekeliruan-kekeliruan yang disebabkan oleh kecenderungan yang melekat dalam sifat manusia. Ketika melihat sesuatu manusia cenderung mengukur dari pandangannya sendiri, tidak mendasarkan pandangannya pada realitas yang dilihatnya. Akibatnya manusia mengabaikan objek yang dilihatnya.

b. Kedua, idol of the cave, yaitu kekeliruan-kekeliruan yang disebabkan subjektifitas manusia karena manusia cenderung prejudice, terlalu yakin pada anggapan sendiri yang dipengaruhi oleh watak, pendidikan, dan pengaruh-pengaruh khusus yang tertanam dalam diri manusia.

c. Ketiga, idol of the market-place, adalah kekeliruan-kekeliruan yang disebabkan manusia terlalu percaya pada bahasa atau kekuatan katakata.

d. Keempat, idol of the theatre adalah sistem-sistem filsafat atau pengetahuan masa lampau yang keliru dalam memersepsi realitas. idos ini menunjukkan bahwa manusia cenderung memercayai pada pengetahuan yang bersumber dari tradisi atau budaya dan telah diwariskan secara turun temurun tanpa pemikiran yang kritis. ${ }^{10}$

Penggunaan metode induktif bacon mengharuskan mencabut hal

${ }^{9}$ Loren Bagus, kamus filsafat, (Jakarta: PT.Gramedia Pustaka Utama, 1996), hlm. 308.

${ }^{10}$ Maksum, pengantar filsafat, hlm. 121. 
yang haqiqi dari hal yang tidak haqiqi dan menemukan struktur atau bentuk yang mendasari fenomena yang diteliti, dengan cara: (1) membandingkan contoh-contoh hal yang diteliti (2) menelaah variasivariasi yang menyertainya, dan (3) menyingkirkan contoh-contoh yang negatif. Maka pertama-tama yang perlu dilakukan adalah mengumpulkan data-data heterogen tentang suatu hal. Kemudian urutannya akan nampak dengan jelas. Yang paling awal adalah peristiwa konkret partikular yang sebenarnya terjadi (menyangkut skema, atu kausa materialnya), baru ditemukan dasar inti. dalam dasar inti ini, pertama-tama dikemukakan dasar inti yang masih partikular, yang keabsahannya perlu diperiksa secara deduktif jika yang ini sudah cukup handal, barulah boleh terus maju menemukan dasar inti yang semakin umum dan luas. Begitulah langkah bacon dalam induksi eksperimennya. ${ }^{11}$

Novum organum atau new instrument mungkin buku bacon terpenting.buku ini dasarnya merupakan pernyataan pengukuhan untuk penerimaan metode empiris tentang penyelidikan. Praktek bertumpu sepenuhnya pada logika deduktifnya aristoles adalah tak ada guna, merosot, absurt karena itu diperlukan metode baru penelaahan, suatu metode induktif. ilmu pengetahuan bukanlah sesuatu titik tempat bertolak dan mengambil kesimpulan darinya. Tetapi ilmu pengetahuan adalah sesuatu tempat sampai ke tujuan. Untuk memahami dunia ini, pertama orang mesti "mengamati" nya lalu kempulkan fakta-fakta kemudian bacon ambil kesimpulan dari fakta-fakta itu dengan cara argumentasi induktif yang logis. Meskipun para ilmuwan tidak mengikuti metode induktif bacon dalam semua segi ide umumnya yang diutarakannya penelitian dan percobaan penting yang ruwet jadi gerak dorong dari metode yang digunakan oleh mereka sejak itu ${ }^{12}$

\section{Auguste Comte dan Paradigma Keilmuannya}

Auguste comte merupakan filosof dan warga negara perancis yang hidup diabad ke-19 setelah revolusi perancis yang terkenal itu. Ia lahir di perancis pada tanggal 19 januari 1978. Ia belajar disekolah politeknik diparis, tetapi ia dikeluarkan karena ia seorang pendukung republik, sedangkan sekolahnya justru rovalistis. Auguste Comte menerima dan mengalami secara langsung akibat-akibat negatif secara langsung revolusi tersebut khususnya di bidang sosial ekonomi, politik, dan pendidikan. Pengalaman pahit yang dilalui dan dialaminya secara

11 Praja, filsafat ilmu, hlm. 326.

12 Praja, Filsafat ilmu, hlm. 327

106 JURNAL LISAN AL-HAL 
langsung bersama bangsanya itu, memotivasi dirinya untuk memberikan alternatif dan solusi ilmiah-filosofis dengan mengembangkan epistimologi dan metodologi sebagaimana buah pikirannya itu tercermin didalam aliran potivisme. Aliran ini menjadi berkembang dengan subur karena didukung oleh para elit ilmiah dan maraknya era industrialisasi saat itu. Comte bukanlah orang yang menyukai hal-hal yang berbau matematika. Tetapi lebih care pada masalah sosial dan kemanusiaan. Bersama dengan henry de'saint simon. Comte mencoba mengadakan kajian problem-problem sosial yang diakibatkan industrialisasi. Karena ketekunan dan kepiawaiannya dalam bidang-bidang sosial menjadikan comte sebagai bapak sosiologi, meskipun comte tidak menguraikan secara lebih rinci masalah apa yang menjadi obyek sosiologi, tetapi ia mempunyai asumsi bahwa sosiologi terdiri dari dua hal, yaitu sosial statis dan sosial dinamis. ${ }^{13}$

Di antara karya-karyanya Auguste Comte, Cours de Philosphie Possitive dapat dikatakan sebagai masterpiece-nya, karena karya itulah yang paling pokok dan sistematis. Buku ini dapat juga dikatakan sebagai representasi bentangan aktualisasi dari yang di dalamnya Comte menulis tentang tiga tahapan perkembangan manusia. Menurut Comte, perkembangan manusia berlangsung dalam tiga tahap. Pertama, tahap teologis, kedua, tahap metafisik, ketiga, tahap positif. 1. Tahap Teologis Pada tahap teologis ini, manusia percaya bahwa dibelakang gejala-gejala alam terdapat kuasa-kuasa adikodrati yang mengatur fungsi dan gerak gejala-gejala tersebut. Kuasa-kuasa ini dianggap sebagai makhluk yang memiliki rasio dan kehendak seperti manusia. Tetapi orang percaya bahwa mereka berada pada tingkatan lebih tinggi dari pada makhlukmakhluk selain insani. Pada taraf pemikiran ini terdapat lagi tiga tahap. Pertama, tahap yang paling bersahaja atau primitif, dimana orang menganggap bahwa segala benda berjiwa (animisme). Kedua, tahap ketika orang menurunkan kelompok hal-hal tertentu, dimana seluruhnya diturunkan dari suatu kekuatan adikodrati yang melatarbelakanginya sedemikian rupa hingga tiap tahapan gejala-gejala memiliki dewa sendirisendiri (polytheisme). Gejala-gejala "suci" dapat disebut "dewa-dewa", dan "dewa-dewa" ini dapat diatur dalam suatu sistem, sehingga menjadi politeisme dengan spesialisasi. Ada dewa api, dewa lautan, dewa angin, dan seterusnya. Ketiga, adalah tahapan tertinggi, dimana pada tahap ini orang mengganti dewa yang bermacam-macam itu dengan satu tokoh HIm. 69.

13 Selamet Imam Santoso, Sejarah Ilmu Pengetahuan (Jakarta: Sirna Hudaya, 1997).

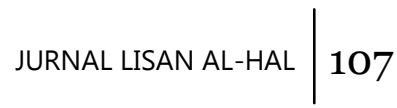


tertinggi (esa), yaitu dalam monotheisme. Singkatnya, pada tahap ini manusia mengarahkan pandangannya kepada hakekat yang batiniah (sebab pertama). Di sini, manusia percaya kepada kemungkinan adanya sesuatu yang mutlak. Artinya, di balik setiap kejadian tersirat adanya maksud tertentu. 2. Tahap Metafisik Tahap ini bisa juga disebut sebagai tahap transisi dari pemikiran Comte. Tahapan ini sebenarnya hanya merupakan varian dari cara berpikir teologis, karena di dalam tahap ini dewa-dewa hanya diganti dengan kekuatan-kekuatan abstrak, dengan pengertian atau dengan benda-benda lahiriah, yang kemudian dipersatukan dalam sesuatu yang bersifat umum, yang disebut dengan alam. Terjemahan metafisis dari monoteisme itu misalnya terdapat dalam pendapat bahwa semua kekuatan kosmis dapat disimpulkan dalam konsep "alam", sebagai asal mula semua gejala. ${ }^{14}$

Ada beberapa sumber penting yang menjadi latar belakang yang menentukan jalan pikiran August Comte, yaitu:

a. Revolusi perancis dengan segala pemikiran yang berkembang pada masa itu. Comte tidaklah dapat dipahami tanpa latar belakang revolusi perancis yaitu pada masa timbulnya krisis sosial yang maha hebat pada masa itu. Sebagai seorang ahli pikir, comte berusaha untuk memahami krisis yang sedang terjadi tersebut. Ia berpendapat bahwa manusia tidaklah dapat keluar adri krisis sosial yang terjadi itu tanpa melalui pedoman-pedoman berfikir yang bersifat scientifik. Filsafat sosial yang berkembang di perancis pada abad ke-18, khususnya filsafat yang dikembangkan oleh para penganut paham ensiklopedis ini terutama dasar-dasar pikirannya, sekalipun kelak ia mengambil posisi tersendiri setelah keluar dari aliran ini

b. Aliran reaksioner dari para ahli pikir Thoecratic terutama yang bernama De Maistre dan De Bonald. Aliran reaksioner dalam pemikiran Katolik Roma adalah aliran yang menganggap bahwa abad pertengahan kekuasaan gereja sangat besar, adalah periode organis, yaitu suatu periode yang secara paling baik dapat memecahkan berbagai masalah - masalah sosial. Aliran ini menentang pendapat para ahli yang menganggap bahwa abad pertengahan adalah abad di mana terjadinya stagmasi didalam ilmu pengetahuan, karena kekuasaan gereja yang demikian besar di segala lapangan kehidupan. Comte telah membaca karya-karya pemikir Theocratic dibawah pengaruh Sain-Simont sebagaimana diketahui Sain-Simont juga

14 Slamet, Sejarah ilmu pengetahuan, hlm. 70. 
menganggap bahwa abad pertengahan adalah periode organic yang bersifat konstruktif.

c. Sumber terakhir yang melatar belakangi pemikiran Comte adalah lahirnya aliran yang dikembangkan oleh para pemikir sosialistik, terutama yang diprakarsai oleh Sain-Simont. Comte telah membangun hubungan yang sangat erat dengan Sain-Simont dan juga dengan para ahli pikir sosialis Prancis lainnya. Comte di satu pihak akan membangun pengetahuan sosial dan dipihak lain akan membangun kehidupan ilmu pengetahuan sosial yang bersifat scientific. Sebenarnya Comte memiliki sifat tersendiri terhadap aliran ini, tetapi sekalipun demikian dasar-dasar aliran masih tetap dianutnya terutama pemikiran mengenai pentingnya suatu pengawasan kolektif terhadap masyarakat, dan mendasarkan pengawasan tersebut didalam suatu dasar yang bersifat scientific. ${ }^{15}$

Comte adalah penyumbang terbesar untuk membangun sosiologi sebagai suatu ilmu. Dalam buku filsafat positifnya, yang pada dasarnya merupakan suatu buku tentang filsafat ilmu pengetahuan dan uraian tentang itu telah mengambil tempat paling banyak dalam bukunya. Comte menguraikan metode-metode berpikir ilmiah. Comte mengatakan bahwa ilmu pengetahuan pada dasarnya tidak lebih dari pada suatu perluasan metode yang sangat sederhana dari akal sehat, terhadap semua faktafakta yang tunduk kepada akal pikiran manusia. Comte sangat mendasarkan seluruh pemikirannya kepada perkembangan atau kemampuan akal pikiran atau intelegensi manusia.

Auguste Comte membagi sosiologi menjadi dua bagian yaitu Social Statics dan Social Dynamic. Sosial dynamic merupakan teori tentang perkembangan dan kemajuan masyarakat, karena social dinamic merupakan study tentang sejarah yang akan menghilangkan filsafat yang spekulatif tentang sejarah itu sendiri. Social statics dimaksudkannya sebagai suatu study tentang hukum-hukum aksi dan reaksi antara bagianbagian dari suatu sistem sosial. Social statics merupakan bagian yang paling elementer dari ilmu sosiologi, tetapi dia bukanlah bagian yang paling penting dari study mengenai sosiologi, karena pada dasarnya social statics merupakan hasil dari suatu pertumbuhan.

Bagian yang paling penting dari sosiologi menurut Auguste Comte adalah apa yang disebutnya dengan social dynamic, yang didefinisikannya sebagai teori tentang perkembangan dan kemajuan masyarakat. Karena social dynamic merupakan study tentang sejarah yang akan

15 Slamet, Sejarah ilmu pengetahuan, hlm. 73. 
menghilangkan filsafat yang spekulatif tentang sejarah itu sendiri.

Social dynamics adalah teori tentang perkembangan manusia. Comte tidak membicarakan tentang asal usul manusia karena itu berada di luar batas ruang lingkup ilmu pengetahuan. Karena ajaran filsafat positif yang diajukannya mengatakan bahwa semua ilmu pengetahuan haruslah dapat dibuktikan dalam kenyataan. Dia berpendapat bahwa di dalam masyarakat terjadi perkembangan yang terus menerus, sekalipun dia juga menambahkan bahwa perkembangan umum dari masyarakat tidak merupakan jalan lurus.

Pembagian sosiologi kedalam dua bagian ini bukan berarti akan memisahkannya satu sama lain. Bila social statics merupakan suatu study tentang masyarakat yang saling berhubungan dan akan menghasilkan pendekatan yang paling elementer terhadap sosiologi, tetapi study tentang hubungan-hubungan sosial yang terjadi antara bagian-bagian itu tidak akan pernah dapat dipelajari tanpa memahaminya sebagai hasil dari suatu perkembangan. oleh karena itu, Comte berpendapat bahwa tidaklah akan dapat diperoleh, suatu pemahaman yang layak dari suatu masalah sosial tanpa mengguanakan pendekatan social dynamic atau pendekatan historis. ${ }^{16}$

Ada banyak hal yang mengganggu perkembangan suatu masyarakat seperti faktor ras manusia sendiri, faktor iklim dan faktor tindakan politik. Comte berpendapat bahwa jawaban tentang perkembangan sosial harus dicari dari karakteristik yang membedakan antara manusia dengan binatang. Menurut Comte, yang membedakan manusia dengan binatang adalah perkembangan inteligensi manusia yang lebih tinggi. Comte mengajukan hukum tentang 3 tingkatan inteligensi manusia, yaitu pemikiran yang bersifat theologis atau fictious, metaphisik atau abstrak, scientific atau positive. Sjarah umat manusia sebenarnya ditentukan oleh pertumbuhan dari pemikiran manusia, hukum tertinggi dari sosiologi haruslah hukum tentang perkembangan inteligensi manusia.

\section{John Stuart Mill dan Paradigma Keilmuannya}

John Stuart Mill adalah putra dari James Mill yang lahir di London pada tahun 1806. Mill muda tidak pernah sekolah, namun ayahnya memberi suatu pendidikan yang sangat baik. Terbukti sejak kecil usia 3 tahun sudah diajari bahasa Yunani, bahasa Latin pada usia 8 tahun, serta ekonomi politik dan logika (termasuk karya asli Aristoteles) pada usia 12 tahun dan mendiskusikannya dengan ayahnya. Selanjutnya Mill

16 Praja, Filsafat ilmu, hlm. 128.

110 JURNAL LISAN AL-HAL 
mempelajari ekonomi, Demonthenes dan Plato khususnya pada metode dan argumentasi.

Pada usia 15 tahun, ia membaca karangan Jeremy Betham dan berhasil mempengaruhi paradigma berfikirnya, sehingga ia mematangkan pendapatnya dan memantapkan tujuannya untuk menjadi "Sosial Reformer" (pembaharu sosial). Ketika berusia 17 tahun, Mill bekerja di India House Company, di mana Ia mengabdi selama tiga puluh lima tahun sampai perusahaan tersebut bubar pada tahun 1853. Selama tahun 18651868 Mill menjadi anggota dalam Lower House parlemen Inggris

Sejak kecil John Stuart Mill juga mendapatkan pendidikan langsung dari pamannya Jeremy Betham. Sehingga tidak mengherankan ketika berusia 20 tahun, Mill sudah terkenal sebagai pemimpin gerakan utilitarianisme yang kritis. Di samping itu, ketika bekerja di India Company, Ia selalu meluangkan banyak waktu untuk melakukan pengembaraan intelektual dan menyebarkan ajaran utilitarianisme melalui surat kabar dan jurnal.

Mengingat pekerjaannya yang begitu intensif, tidaklah mengherankan bahwa pada tahun 1826 ia mengalami keambrukan karena sakit saraf. Namun, krisis mental itu mempunyai efek yang positif. Ia mulai membebaskan diri dari filsafat Jeremy Betham dan mengembangkan pahamnya sendiri tentang utilitarianisme. Paham ini dirumuskannya dalam essay Utilitarianism dari tahun 1864, yang kemudian menjadi bahan sebuah diskusi hebat selama hampir seluruh akhir abad ke 19, terutama di Inggris. Paham khas tentang utilitarianisme yang dirumuskan Mill merupakan sumbangan penting kepada filsafat moral. Ia meninggal di Avigron di Prancis pada tahun 1873.

Mill adalah seorang penulis yang produktif. Tulisan-tulisannya tentang ekonomi dan kenegaraan dibaca luas. Salah satu tulisannya paling gemilang dalam etika politik segala zaman adalah bukunya On Liberty di tahun 1859, yang merupakan pembelaan kebebasan individu terhadap segala usaha penyamarataan masyarakat. Tulisan lainnya yang penting adalah System of Logic; Principles of Political Economy, Considerations on Representative Government, dan Subjection of Women. Mill menjadi tokoh intelektual liberalisme Inggris kedua yang tidak lagi membela paham laissez faire klasik, melainkan memperhatikan tuntutan-tuntutan keadilan social. ${ }^{17}$

John Stuart Mill menyatakan bahwa ada dua sumber pemikiran

17 Ahmad Shukri Moh, Konsep, Teori, Dimensi Isu Perkembangan (Malaysia: Muapakat Jaya, 2003), hlm. 55. 
utilitarianisme pertama, dasar normatif artinya suatu tindakan dianggap benar kalau bermaksud mengusahakan kebahagiaan atau menghindari hal yang menyakitkan dan buruk kalau bermaksud menimbulkan hal yang menyakitkan atau tidak mengenakkan kedua, dasar psikologi artinya dalam hakikat manusia berasal dari keyakinannya bahwa kebanyakan,dan mungkin saja semua orang punya keinginan dasar untuk bersatu dan hidup harmonis dengan semua manusia ${ }^{18}$

\section{Simpulan}

Paradigma ilmu berfungsi memberikan kerangka, mengarahkan, bahkan menguji konsistensi dari proses keilmuan. Tidak hanya itu, paradigma ilmu juga berfungsi sebagai lensa para ilmuan dan dapat mengamati memahami masalah-masalah ilmiah dalam bidang masingmasing dan jawaban-jawaban ilmiah terhadap masalah-masalah tersebut.dan paradigma merupakan sebuah jendela tempat orang mengamati dunia luar dan tempat orang bertolak menjelajahi dunia dengan wawasannya berikut sudah dipaparkan tentang pemikir sang filosof rene descartes dimana pemikirannya mengatakan bahwa Descartes menganggap benar segala pengetahuan bersumber dari rasio manusia. Bahwa tidak ada satupun hal yang tidak dapat diketahui oleh manusia asalkan manusia mau menggunakan nalarnya. hal itu justru membuktikan dengan jelas dan pasti bahwa dia ada. Hal ini kemudian menjadi aksiomanya yang paling terkenal, "saya berpikir, maka saya ada". Akhirnya, hal ini menjadi prinsip pertama dari filsafatnya.sedangkan menurut pandangan bacon bisa dikatakan praktis sebuah pengetahuan itu berasal dari sebuah pengalaman, dan pengalamanlah yang menjadi sebuah dasar pengetahuannya seperti kata yang sering didengar bahwa "experience is the best teacher" dan pengetahuan termasuk penguasa "power".lalu mengenal sebuah pemikiran comte yang mengandung makna bahwa bapak sosiologi ini mengungkapkan segala pemikirannya dipengaruhi oleh berbagai keadaan dan tokoh pemikir lainnya yang mendominasi pada saat itu, model filsafatnya begitu mengagungkan akal dan panca indera manusia sebagai tolak ukur kebenaran, namun kebenaran termasuk salah satu pokok permasalahan pengetahuan manusia tapi tidak sepenuhnya milik manusia hanya perlu menghampiri dan mendekati dengan cara tertentu .lalu terakhir john stuart mill manusia memerlukan keyakinannya dan menyatukan keiginannya untuk menjaga keharmonisan antara sesama manusia.

18 Shukri ,konsep, hlm. 56.

112 JURNAL LISAN AL-HAL 


\section{DAFTAR PUSTAKA}

Bagus, Loren, kamus filsafat, Jakarta: PT Gramdia, 1996

Hadiwijono, harun, Seri filsafat Baru, Yogyakarta: Kanisius, 1980

Juhaya S. Praja, Aliran-Aliran Filsafat Dan Etika, Bandung: Kencana, 2003

Maksum, Ali,Pengantar Filsafat, Yogyakarta: Ar-Ruzz Media, 2011

Norman, Smith. New Studies In The Philosophy, New York: Russek, 1996

Praja, Juhaya, Filsafat Ilm, Bandung: Kencana, 2003

S, Junjun. Filsafat Ilmu Sebuah Pengantar Populer, Jakarta: Pustaka Sinar, 2003

Santoso, Imam, Sejarah ilmu pengetahuan, Jakarta: Sirna Hudaya, 1996

Shukri, Ahmad, Konsep Dan Teori, malaysia: Muapakat, 2003

Solomon, kathleen, A Short History Of Philosophy, New York: Oxford University, 1996 
"Telaah Paradigma Keilmuan"

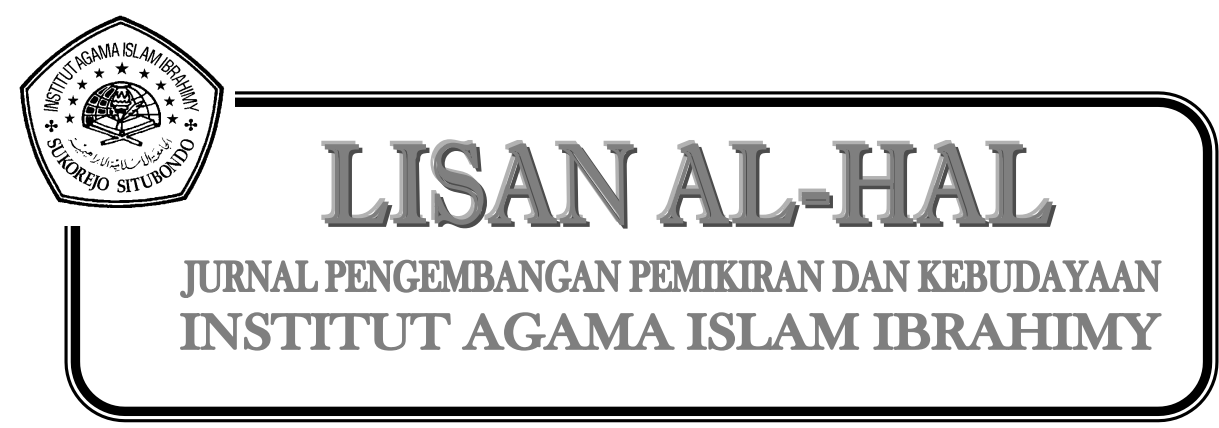

$114 \mid$ JURNAL LISAN AL-HAL 